\title{
Literary Creation: Insights from Sanskrit Literary Critics
}

\author{
Panduranga Charanbailu Bhatta \\ Professor, Business Ethics and Communication Group, \\ Indian Institute of Management CalcuttaJoka, D.H. Road, Kolkata-700104, India
}

\begin{abstract}
All aspects of literary creation, from creation to expression, have been recorded with perceptive insights and in minute detail by the renowned Sanskrit literary critics. The main topics dealt with by these critics are: the definition and classification of literary creation, viz., poetry, prose, drama etc; the figures of speech (alamkaras), the sentiments (rasas), literary merits and defects (gunas and doshas), style (ritis), and purpose (prayojana). They discuss important ingredients of literary creation such as creative talent (pratibha), erudition (vyutpatti) and practice (abhyasa), the problem of coincidence (samvada), inexhaustible resources, etc. A great literary creation is one that has great imageries, natural descriptions, exquisite miniatures, precious maxims and keen observations of men and matter, besides revealing deep understanding of human character. It exhibits precise phrasing, proportion and restraint, delicacy, sensitiveness, and above all, a profound suggestiveness. Sanskrit literary critics' views on the relative importance of word and sense in literary creation, their concept of poetry which has spontaneous expression of a deeply felt emotion as its essence, their appeal to make new literary creation, their views on what is essential for literary creation-all these are very valuable contributions towards literary creation. The main purpose of this paper is to help budding literary creators in any language irrespective of time and place by providing new insights.
\end{abstract}

Keywords: creative talent, suggestion, equipments of literary creation, aesthetics, Sanskrit poets

\section{Introduction}

Long literary heritage in Sanskrit language has resulted in creating a standard literary taste and due to this a very large number of works on literary criticism came to be composed in that Language. The entire field of Sanskrit literary criticism may be regarded as one continued attempt to understand and appreciate literary creation. All aspects of literary creation, from creation to expression, have been recorded with perceptive insights and in minute detail by the great Sanskrit literary critics.

The prime concern of Sanskrit literary criticism is a search for the "soul" of poetry. It recognizes the uniqueness of aesthetic experience and made it the primary purpose of literary creation. The main topic dealt with by the Sanskrit literary critics are the definition and classification of literary creation, viz., poetry, prose, drama etc; the figures of speech (alamkaras), the sentiments (rasas), literary merits (gunas) and defects (doshas), style (ritis), and purpose (prayojana).

There are different schools of thought in the field of literary criticism, each school approaching the subject from a different point of view. The main point of enquiry is what constitutes the essence of literary creation and how to achieve it? Anandavardhana (9th C.A.D), a renowned Sanskrit literary critic established suggestion (dhvani) as the soul of poetry. He came out with a new scheme, where all the different elements of literary creation are systematically and harmoniously assigned their own places. One of the main objectives of this paper is to understand and appreciate the literary creation as discussed by Sanskrit literary critics. They have shown deep interest in analysing the issue of literary creation and answered various questions related to creative talent, equipments that are essential, inexhaustible resources for literary creation, the problem of coincidence etc. This paper also focuses on the assessment of a poet made by a renowned Sanskrit literary critic that is highly beneficial to the budding literary creators in any language irrespective of time and place.

\section{Creative Talent}


According to Sanskrit literary critics, creative talent called pratibha is the foundation of literary creation. It is like a seed without which nothing can grow and one cannot create good poetry, prose, and drama without this basic talent. Pratibha literally means a flash across the mind-a revelation characterized by 'immediacy and freshness'. Pratibha is that faculty of the mind which is capable of original creation. ${ }^{1}$ Pratibha helps a person to have visions, which are ever new, steeped in beauty, unforeseen events, incidents, concepts and ideas. It provides him/her with wonderful insights to correlate all complex things, arrange and rearrange. Literary creators do not merely see dreams and do not merely entertain everrefreshing ideas; they translate them into reality. They experience intense feelings at first and then they recount their impressions when their mind is tranquil. Thus there are two aspects of literary creation process viz. having emotional moods and ideas at first (talent) and then communicating them through suitable words (expression). A conception, however original it might be, it is not appreciated until it is expressed in appropriate words or converted into literary creation. Philosophers hold that one possessed an intuition only to the extent one is able to express it, at least to oneself. A conception taking its rise in imagination of a poet will not have attained perfection at the very first flash. ${ }^{2}$

At best it will be like a precious stone dug out of the mine, with its native appearance hardly to be distinguished from that of a piece of stone. It needs polish before it can shine with full lusture; this it undergoes in the process of literary creation. That is to say, it is in being expressed or created that a creative talent defines itself.

\section{Equipments}

For literary creation one is expected to acquire all-round knowledge. Erudition (vyutpatti) is an aid to creative talent (pratibha) because erudition lends power of discretion. Erudition in the real sense is not the acquisition of wide knowledge; it indicates an in-depth study that leads to power of discretion, the ability to distinguish the suitable from the not so suitable material. ${ }^{3}$ Whether a person endowed with creative talent but devoid of erudition or training can produce good poetry is a topic that is discussed to a great length by many Sanskrit literary critics. People without formal education have been able to create good poetry. This is best explained through the statement of Kalidasa, the famous Sanskrit poet, who says that 'Creepers in the wilderness can surpass creepers in the garden'. ${ }^{4}$ There are instances of scholars well-versed in different branches of learning unable to compose a single line. Sanskrit critics mention two types of creative talent:

(1) inborn talent (sahaja pratibha),

(2) acquired talent (aharya pratibha).

Inborn talent operates due to impressions of the past births. ${ }^{5}$ Acquired talent requires hard work and rigorous training. Proficiency and practice are acquired through an effort; therefore, so far as, these are concerned a creative person is made. One cannot become creative until and unless one has got some intrinsic creative talent. At the same time this faculty alone is not enough for producing literary creations worth the name. Rajasekhara, a celebrated literary critic refers to eight equipments as necessary conditions for literary creation. ${ }^{6}$ They are:

Peace of mind

Intuition

Practice

Devotion

Participation in the assembly of the learned

All inclusive knowledge

Strong memory

Courage

According to Abhinavagupta the seven factors, essential equipments of the creation of good poetry are?:

Aesthetic susceptibility

Power of visualization 
Intellectual background and close observation of facts of nature

Contemplative habit

Capacity to identify

Freedom from purposive attitude

Freedom from personal joys and sorrows.

Concentration, which means oneness of mind or single mindedness in which all other thoughts are withdrawn, is given due importance in literary creation as it facilitates the process. It is a method of withdrawing the mind from going to external objects. When the mind is fully concentrated, it can perceive new objects and new ideas can occur in it. Some Sanskrit critics advocate selection of proper time and place. Proper place according to them is the place free from human beings. ${ }^{8}$ Solitude or loneliness helps one to concentrate on the creative idea or its expression. Some writers suggest the early morning or fourth quarter of the night as congenial for any intellectual/creative activity. As it is fresh after night's rest, concentration becomes easier. There is no doubt about the fact that if the brain is to function at its best solitude is necessary. Anthony Storr says,

Learning, thinking, innovation and maintaining contact with one's inner world are all facilitated by solitude. ${ }^{9}$

It is to be noted that ancient Sanskrit critics while attaching the greatest importance to pratibha as the direct cause of literary creation did not lose sight of other factors that go to assist in literary creation. This corroborates an observation made by JC Shairp:

While Imagination, working in these and other ways, is the poet's peculiar endowment, it is clear that for its beneficent operation there must be present an ample range, a large store of material, on which to work. This it cannot create for itself. From other regions it must be gathered from a wealth of mind in the poet himself, from large experience of life and intimate knowledge of nature, from the exercise of his heart, his judgment, his reflection, indeed of his whole being, on all he has seen and felt. In fact, a great poet must be a man made wise by large experience, much feeling and deep reflection, when many conditions are present, then and then only can his imagination work widely; benignly, and for all time. ${ }^{10}$

In favour of above citation, we may consider the example Banabhatta (7 $7^{\text {th }}$ C. A.D.) the celebrated author of Kadambari and Harshacharita, two great prose works of Sanskrit literature. Bana has given a new literary dimension to Sanskrit prose. Bana was born in an affluent family and had also received an all-round education in sacred and secular subjects. Bana's real greatness lies in the delineation of various characters invented by him, the emotions felt by them and their reaction to the circumstances in which they find themselves. The reader is completely mesmerized by the picture presented to him and he feels that he himself had been experiencing all that. How Bana could give such realistic pictures of his characters? The answer probably lies in the fact that Bana on completion of the routine studies, went on a long tour to different regions, where he met different scholars and had a first-hand experience of the customs and manners of the people. He travelled with a big company of people that included forty-four members, each one with a special attainment in the arts and crafts of the time. Some of them were poets, a few were philosophers and quite a few were artists. His team included magicians and musicians, gamesters and dice-players, actors and scribes, Buddhist monks and nuns, jewelers and physicians, ascetics of different denominations, and story tellers, potters, shampooers, personal attendants, gold smith, painter, sculptor, drummer, singers, flute-players, female dancer, mineralogist, and snake charmer. Thus Bana had managed to get around him persons proficient in various arts, and representatives of various strata of society. In short, his travels contributed as much as his learning to shape his innate creative talent.

The rich qualities of Bana's head and heart are evident in almost every page of his literary creations. His perfect literary style must have been the result of his wide learning, especially in the literary art. He shows an intimate knowledge of the ancient Indian historical and mythological tradition embodied in epics and old narratives.

His mastery of literary theory is complete, extending to the most difficult figures of speech like paradox, alliteration, hyperbole and poetic fancy. He was also well read in all the schools of Indian philosophy and in all the miscellaneous arts and sciences of the time. Grammar, prosody, erotic, Buddhism and Jainism-all this formed part of his equipment. ${ }^{11}$

Inexhaustible Resources and the Problem of Coincidence 
All sorts of ideas and expressions are capable of being constituents of poetry. Namisadhu, commentator on Rudratas's Kavyalamkara says,

There is no such word nor any meaning, no proverbial saying, no art that cannot

become a part of poetry. Indeed poet's burden is great. ${ }^{12}$

This gives tremendous hopes to those who are involved in literary creation. Andavardhana the author of Dhvanyaloka says,

There is nothing on earth which cannot serve as grist to the mill of a person gifted with genius and everything can be transmuted into a thing of beauty. ${ }^{13}$

He says further:

Though primordial Nature has been responsible for the creation of numerous worlds containing varied objects over a cycle of several centuries, it is not possible to say even now that her ability for the creation of new objects has diminished even by an iota. ${ }^{14}$

Therefore, there is no scarcity of resources for new literary creation. It all depends on possessing and nurturing creative talent. The very same thing that may look dull and devoid of beauty becomes full of energy and charming due to creative touch. Anadavardhana has a beautiful simile to explain this creative process. He says, it is just like the "spring season transforming an ordinary creeper into beautiful object"15

There are bound to be plenty of coincidences amongst great minds. But all of them should not be regarded by the wise as being identical. Further, Anandavardhana points out how they are not identical. Coincidence in creative persons is just another name for the similarity of one with another. It is of three kinds:

(1) like that of a reflected image of persons,

(2) like that of a painted picture of persons,

(3) like that of living persons resembling each other.

Some creative works are like reflections of other works. Some others are like painted pictures of other works; still others are just similar to other works. An intelligent man should avoid the first kind of coincidence, viz., that like a reflected image, because it has no separate life of its own or, in other words, not even a real body of its own.

The second kind of coincidence, viz. that like a painted portrait also deserves to be avoided, since its soul is nothing but a nonentity though it has a body of its own. But the third kind of coincidence need not be rejected by the creative person at all, since it possesses a lovely body of its own which is real (as well as a distinct soul). It is not at all possible to affirm that two living persons who bear a close resemblance of features are identical with each other. ${ }^{16}$ Thus Sanskrit critics open up fresh and beautiful vistas for literary creation by immensely widening the scope of resources.

Anandavardhana says that there would have been only two or three poets in the world; no good poetry could possibly be produced without in some manner or other using some phrases, some expressions and some beautiful ideas from the works of previous authors. In fact, there is nothing new under the sun. Creative talent enables one to express a single idea in a thousand agreeable ways. Creative persons need not be under the impression that only new ideas should be thought after and that there is no virtue in using what others have already tried. Though thousands and thousands of poets write poetry, the scope of poetic art would in no way be curtailed by that, and the resources of creative persons like the resources of Nature can never be exhausted. Anadavardhana says,

The Goddess of Speech, Sarasvati, herself will provide the desired ideas for a good poet whose mind is averse to borrowing the belongings of another. ${ }^{17}$

\section{Literary Critic's Assessment of a Poet}

As mentioned earlier, Anandavardhana is the foremost among Sanskrit literary critics. His theory on literary creation and standards of literary criticism set forth in his Dhvanyaloka became a model for almost all literary critics in India. He emphasized the technique of suggestion and the importance of emotional appeal in poetry. ${ }^{18} \mathrm{He}$ has laid down the principles to be observed by the poets in order to ensure emotional appeal and evolved the principles of literary criticism enabling a 
critical reader to appreciate the artistic merits of poetry in general and suggestive poetry in particular. ${ }^{19} \mathrm{He}$ assessed Kalidasa, the master poet in Sanskrit, in the course of his exposition of the theory of suggestion in literary creations. This assessment reflects the mature judgment of a true critic and throws new light on Kalidasa's literary creations. This assessment is certainly of considerable significance for a correct and full appreciation of literary creations.

Anadavardhana has made a comparative study of Kalidasa's works with their original sources and has come to the conclusion that the poet effected necessary modifications in the original stories and wove into them incidents and situations of his own invention with a view to produce sentimental charm. A crude story selected by the poet from a well-known source may have the potential to be the basis of a literary composition brimming with emotional beauty, but it may not be suitable for ready adoption without any modifications. In such cases the poet should prune the story with a view to leaving out what is not congenial for the delineation of the sentiment. Further, he should expand the story by suitable incidents which are the creation of his own poetic imagination. Anadavardhana mentions Kalidasa's works as model in this respect. ${ }^{20}$ As an example we may cite the transformation of original Sakuntala story found in the Mahabharata into a world famous drama viz, Abhijnanasakuntala by Kalidasa.

As one reads the original story, one hardly thinks it is capable of supplying the greatest of Sanskrit dramatists with the necessary plot for the most renowned of his works. Yet the fact is there, that into this dry unromantic skeleton Kalidasa has breathed the life of romanticism and animation. ${ }^{21}$

Among such modifications, attention may be drawn to a few that are most significant. The simple and outspoken forestbred maiden quite typical of the epic age, does not appeal to the poet as a suitable heroine, for delineating love in all its elegance, and he artistically transforms her into a dignified and romantic damsel susceptible to the influence of love and capable of sweet reactions to its impact. Judging correctly that the hermitage will not afford the proper atmosphere for the love intrigues, he has shifted the scene to the grove which with its natural beauty affords effective excitements of love. By introducing two new characters Kalidasa creates an atmosphere of sincere friendship and sweet sympathy in which love grows freely and steadily. Goethe, the master poet of Europe, has summed up his criticism of Sakuntala in the following lines:

Would'st thou the young year's blossoms

and the fruits of its decline,

And all by which the soul is charmed,

Enraptured, feasted, fed,

Would'st thou the Earth and Heaven itself

in one sole name combine?

I name thee, O Sakuntala! and all at

once is said. ${ }^{22}$

This is a very significant tribute paid by Goethe. He says expressly that Sakuntala contains the history of a developmentthe development of flower into fruit, of earth into heaven, of matter into spirit. In fact there are two unions in Sakuntala; and the motif of the play is the progress from the earlier union of the first Act, with its earthly unstable beauty and romance, to the higher union in the heavenly hermitage of eternal bliss described in the last Act. This drama was not meant for dealing with a particular passion, not for developing a particular character, but for translating the whole subject from one world to another-to elevate love from the sphere of physical beauty to the eternal heaven of moral beauty. ${ }^{23}$

Kalidasa has introduced new devices to achieve novelty in his descriptions. Sanskrit poets describe natural phenomena like mountains, rivers and forests not only in their material form, but also crediting them with an appropriate sentient personality and attributing to them the behavior of dignified human beings.

The beautiful places, the rivers, lakes, plants, hills, valleys, forests etc, captivated Kalidasa's mind, they have become vivid in his poems and dramas as a result of very skilfull delineation by him. To Kalidasa Nature appears to be alive. She is 
conscious. Nature is very sympathetic towards man. She respects the sentiments of man and moves with the perfect knowledge of the moods and fancies of the latter. This is evident in certain sketches, which the poet has presented.

Even a cursory look at the imagery in Kalidasa's works would prove that images appear themselves to him spontaneously as he is engaged in literary creation. In spite of a rush of images in close succession one after the other his sense of poetic proportion usually curbs any possible enthusiasm to overburden his poetry with imagery. But there are a few instances which indicate that he has succumbed to the temptation of overdoing the imagery in his compositions. Anadavardhana appears to exempt Kalidasa from this defect as he says even though Kalidasa has occasionally overdone figures of speech in his poetry, he takes ample care to see that they occupy only a subordinate position and never spoil or eclipse the emotional beauty of his poetry. ${ }^{24}$

In lyrics, epics, dramas and other similar literary creations various sentiments are bound to be described; but a poet intent on enhancing the emotional appeal of his work should adopt one of them as the principal sentiment, assigning to others only a subordinate position. ${ }^{25}$ It requires great skill and training on the part of the poets to harmonise different sentiments in their works, giving predominance to one of them and keeping others as subsidiaries. The description of conflicting sentiments and moods without prejudice to the principal one, offers a challenge to the genius of a poet. Kalidasa, in the estimate of Anandavardhana takes up this challenge and comes out successful in all glory. Another aspect of Kalidasa's literary creations appreciated by Anadavardhana is worth noting here. According to him the descriptions of Kalidasa have a freshness and charm of their own due to the predominating element of suggestion. While ordinary poets express their ideas in a crude and blunt manner and use words in their conventional meaning, Kalidasa successfully employs the technique of suggestion in his composition. The greatness of a poet depends on the suggestive character of his works. To achieve greatness, a poet should become conscious of the importance of suggestion and master the necessary technique and successfully press it into service in his literary creations. A poet desiring recognition as a great poet should cultivate mastery over the sense and the word that possess the power of suggestion. ${ }^{26}$

It is only by the effective employment of suggested sense and suggestive expressions that a poet attains the status of a great poet; on the contrary, if he confines himself, in the conventional way, to the expressed sense and to words conveying the ordinary meaning, he is bound to fail in realizing his ambition. ${ }^{27} \mathrm{~A}$ great poet with the spirit of suggestion should harmonise the ideas and figures with suggestion of sentiment in a spontaneous manner by a single effort of his mind without any distraction. ${ }^{28}$

Kalidasa brought refinement and elegance to Sanskrit poetry. His style is chaste and pure. The laxity noted in the language of the earlier narratives (Puranas) is conspicuously absent in his compositions. The extravagant and scholastic diction of the later Sanskrit authors that appears to be artificial is also absent in Kalidasa. He had a unique skill in presenting his matters in a very precise and effective manner. Brevity, in fact, is the hallmark of his poetry. While other poets in delineating emotions compose a large number of verses and create a pathetic effect by bringing the sentiment to the brink of boredom, Kalidasa by his artistic insight produces a more attractive and delightful picture by reproducing the content within a limited extent. He has avoided elaboration in all the spheres, which is likely to mar the spirit of narration or bring monotony to it. He has displayed an unprecedented wisdom in maintaining restraint in all kinds of sketches, which is definitely a product of his deep artistic feeling and keen observation of beauty. This perfect harmony between sound and sense of expression and idea has characterized his writing. ${ }^{29}$ Again he has no equal in imagery and simile and in natural descriptions. His miniatures are exquisite and precious maxims and observations are strewn over his writings and he reveals his deep understanding of human character in his works. He is unparallel in his choice of precise phrasing, proportion and restraint, delicacy, sensitiveness, and above all, a profound suggestiveness,-qualities that should pertain to all great literary creation, whatever its place or period of origin..$^{30}$

Kalidasa is famous for similies as the saying goes upama kalidasasya. Similies, metaphors and imagery are not mere embellishments; they are the doors through which the poet's vision reaches out on all sides, and reveals things in an undreamt of relatedness. They are not external additions but are of the very texture and making of the poet's expression. Kalidasa is exceptionally rich in similes. The main features of Kalidasa's similes are variety, grace, aptness and suggestiveness.

They are drawn from diverse fields, from flora and fauna, from the other aspects of nature, from human behavior, from old literature, myth and tradition, from the different arts, and from intellectual concepts and abstractions. 
In the sphere of literature a word cannot exist without a significant sense and no sense can be imagined except through words. This togetherness of word and sense constitutes the texture of literary creation. But this also means that words are important in literature only in so far as they convey a sense, namely the intent of the poet, the emotional experience he intends to communicate. The poets often forget, particularly in the composition of longer poems and in narrative or descriptive passages, the relative importance of word and sense, and are tempted to play with words only. ${ }^{31} \mathrm{It}$ is true that the play with words has an ornamental effect; figures of word like alliteration, rhyme, and the picturesque arrangement of letters which is particular feature in Sanskrit poetry, owe their existence to word-play. It has a charm of its own; but it is not true or high poetry by common consent. As a matter of fact, renowned literary critics had pointed out that poetry which has charm only of words and patterned arrangement of words, and of the manufactured ornaments of rhetorical figures, is of a very low order. ${ }^{32}$ Kalidasa was aware of this important concept related to the proper function of word and sense, and of the nature of best poetry and it is a very important insight in creating good poetry. ${ }^{33}$

In conclusion, it may be said that the Sanskrit literary critics' views on the relative importance of word and sense in literary creation, their concept of poetry which has spontaneous expression of a deeply felt emotion as its essence, their appeal to make something new, their views that natural talent, profound and genuine scholarship and the continued practice are the essential factors for literary creation-all these are very valuable contributions towards literary creations and it is of great significance to note that ns of success in literary creation.

\section{References:}

[1] Kane, P.V, History of Sanskrit Poetics, Motilal Banarsidass, Delhi, p.348 for a quotation from

[2] Bhattatauta's Kavyakautuka; Locana on Dhvanyaloka, pp.34 and 164.

[3] Krishnamoorthy, K. The Dhvanyaloka And Its Critics, Bharatiya Vidya Prakashan, Delhi,

[4] 1982, pp.325 ff; Natavarlal Joshi, Poetry, Creativity and Aesthetic Experience, Sanskrit

[5] Poetics and Sanskrit Criticism, Eastern Book Linkers, Delhi, 1994, Pp. 51-76.

[6] Rudrata's Kavyalamkara, I.18.

[7] Kalidasa's Abhijnanasakuntala, I.16.

[8] Kavyamimamsa, p.12; See also Natvarlal Joshi, Poetry, Creativity and Aesthetic Experience,

[9] Eastern Book Linkers, Delhi, 1994.

[10] Kavyamimamsa, X, p.49.

[11] Deshpande. G.T. Abhinavagupta, Sahitya Akademi, Delhi, 1989, p.17.

[12] Vamana's Kavyalamkarasutra, I.3.17

[13] Anthony Storr, Solitude, London, 1974, p.28.

[14] Shairp, J.C, The New Criticism, p. 9.

[15] Krishnamoorthy, K. Banabhatta, Sahitya Adademi, New Delhi, 1994, pp.3-4, 8; Karmarkar,

[16] R.D, Bana, Karnatak University, Dharwar, 1964, pp.2-5.

[17] Namisadhu's commentary on Rudrata's Kavyalamkara, I.19.

[18] Anandavardhana's Dhvanyaloka, IV.10.

[19] Dhvanyaloka, IV, 1.

[20] lbid.

[21] Ibid. 11-14

[22] Ibid, 17.

[23] Dhvanyaloka, P.545 (Kasi Sanskrit Series 135, Varanasi, 1940).

[24] Ibid, p.516.

[25] Ibid., p.335.

[26] See the introduction to the Abhijnanasakuntala edited by A.B. Gajendragadkar, p.

[27] XIX Fifth Edition, Popular Publishing House, Surat, 1951,pp.7-15.

[28] Ibid. p.14.

[29] Rabindranath Tagore's introduction to Arthur W. Ryder's Translation of Abhijnanasakuntala

[30] of Kalidasa, Dover Publications, Inc, Mineola, New York, 2003, pp.iii.

[31] Narayana Pillai, P.K, Kalidasa: An Assessment by Anandavardhana, Vishveshvaranand

[32] Vedic Research Institute, Hoshiarpur, 1974. p.20

[33] Dhvanyaloka, Kasi Sanskrit Series 135, Varanasi, 1940, p.378.

[34] Ibid p.97. 
[35] Ibid, pp. 97-98.

[36] Ibid, p.222; Tilakasiri, Kālidāsa and the Dhvani Theory in Dr. V. Raghavan Felicitation Vol.,

[37] Motilal Banarsidas, Delhi, 1975.

[38] Ghosal, S.N, Kalidasa, An Estimate of His Literary Merit, The World Press Pvt. Ltd,

[39] Calcutta, 1971.pp 99-108; T.G, Kalidasa: His Art and Thought, Poona, 1962

[40] Raghavan, V. On Kalidasa, Kavyalaya Publishers, Mysore, 1980, pp.6, 12, 18-19; Alterkar,

[41] M.D, Aesthetics of Kālidāsa, Vikrama Volume, Ujjain, 1948.

[42] Krmarkar, R.D, Kalidasa, Karnatak University Dharwar, pp.153-156; 157-170;

[43] Subhana, N.R, Kālidāsa, Citations, Meharchand Lacchman Das, Delhi, 1971.

[44] Ram Gopal, Kalidasa; His Art and Culture, Concept Publishing Company, New Delhi, 1984,

[45] pp.42-43.

[46] Bhat, G.K, Appointment with Kalidasa, L.D. Institute of Indology, Ahmedabad, 1982, pp.83-

[47] 84;

[48] Sabnis, S.A, Kālidāsa, His Style and His Times, Published by N. M. Tripathi, Bombay,

[49] 1966. 